\title{
Proteins Involved in Energy Metabolism and Oxidative Regulation Associated with Genotypic Variations in Drought Tolerance for Tall Fescue
}

\author{
Jianming Sun \\ Institute of Animal Science, Chinese Academy of Agricultural Sciences (CAAS), Beijing 100094, \\ P.R. China; and Department of Plant Biology and Pathology, Rutgers University, New Brunswick, \\ NJ 08901 \\ Yiming Liu \\ Tropical Crops Genetic Resources Institute, Chinese Academy of Tropical Agricultural Sciences \\ (CATAS)/Key Laboratory of Crop Gene Resources and Germplasm Enhancement in Southern China, \\ Ministry of Agriculture, Danzhou, Hainan, 571737, P.R. China \\ Xianglin $\mathbf{L i}^{1}$ \\ Institute of Animal Science, CAAS, Beijing 100094, P.R. China \\ Bingru Huang ${ }^{1}$ \\ Department of Plant Biology and Pathology, Rutgers University, New Brunswick, NJ 08901
}

\begin{abstract}
AdDitional INDEX words. Festuca arundinacea, Lolium arundinacea, proteomics, water stress
Abstract. Protein metabolism plays an important role in plant adaptation to drought stress. The objective of this study was to identify drought-responsive proteins associated with differential drought tolerance for a tolerant genotype (RU9) and a sensitive genotype (RU18) of tall fescue (Lolium arundinacea). Plants of both genotypes were grown under well-watered conditions or subjected to drought stress by withholding irrigation for 12 days in a growth chamber controlled at the optimal growth temperatures of $23 / 18{ }^{\circ} \mathrm{C}$ (day/night). Physiological analysis demonstrated that RU9 was relatively more drought tolerant than RU18, as shown by the higher leaf net photosynthetic rate (Pn) and photochemical efficiency at 12 days of drought treatment. Differentially expressed proteins between RU9 and RU18 exposed to drought stress were identified by two-dimensional electrophoresis and mass spectrometry (MS). Several proteins [photosystem I reaction center subunit II, Rubisco small subunit, and Glyceraldehyde-3-phosphate dehydrogenase (GADPH)] in photosynthesis, respiration, or oxidative regulation exhibited higher abundance in RU9 than RU18 under drought stress. These results suggested the critical importance of energy and oxidative metabolism in tall fescue adaptation to drought stress. Those abundant proteins in the drought-tolerant genotype could be used as biomarkers or developed to molecular markers to develop elite drought-tolerant germplasm in tall fescue and other cool-season perennial grass species.
\end{abstract}

Water availability for irrigation of turfgrass species used on landscapes, parks, and sport fields has been declining due to limited rainfall or water use restriction in many areas, which is a major factor causing the decline in turf aesthetic quality and physiological functions (Fry and Huang, 2004). Use of genetic variability in drought tolerance in breeding selection or through genetic modification has made significant progresses in developing drought-tolerant cultivars of various turfgrass species, including tall fescue. Tall fescue is a widely grown cool-season species throughout the temperate regions of the world (Mefti et al., 2016). A previous study found that tall fescue exhibits a wide range of genetic variability in drought tolerance (Ebrahimiyan et al., 2013; Pirnajmedin et al., 2015; Salehi et al., 2014). However, the metabolic mechanisms underlying

Received for publication 12 Mar. 2018. Accepted for publication 15 May 2018. The authors wish to thank the New Jersey Agricultural Experiment Station and Center for Turfgrass Science at Rutgers University for supporting this research project. Thanks to Stephanie Rossi and Cathryn Chapman for critical review of the manuscript.

${ }^{1}$ Corresponding authors. E-mail: huang@aesop.rutgers.edu or lixl@iascaas. net.cn. the genetic variations in drought tolerance of cool-season turfgrasses, including tall fescue are still not completely understood.

Protein metabolism plays essential roles in regulating plant tolerance to various stresses, including drought stress. Effects of drought stress on proteins involve complicated processes, including acceleration of the denaturation, proteolysis, and unfolding of some proteins and induction of some stressprotective proteins, such as dehydrins and chaperones (Obidiegwu et al., 2015; Pinheiro and Chaves, 2011). Proteomic profiling using two-dimensional electrophoresis is a powerful and widely used approach for the identification of proteins and metabolic pathway-regulating plant stress tolerance. Many drought-responsive genes have been identified through proteomic profiling, as reported in limited number of perennial grass species and mostly in annual crops, such as rice [Oryza sativa (Ali and Komatsu, 2006)], soybean [Glycine max (Khan and Komatsu, 2016)], wheat [Triticum aestivum (Faghani et al., 2015)], and barley [Hordeum vulgare (Wang et al., 2015)], which were found to be involved in different metabolic processes, such as antioxidant metabolism, chaperones, cell wall biosynthesis, energy metabolism, and hormone metabolism. A 
previous study with tall fescue, which was exposed to drought stress for $11 \mathrm{~d}$ with field water capacity declining to $\approx 17 \%$, found 10 differentially expressed proteins between two genotypes differing in drought tolerance, which were mainly involved in photosynthesis in chloroplasts (Kosmala et al., 2012). Protein responses to drought stress largely depend on the drought treatment duration, and protein expression associated with genetic variations in drought tolerance may also differ with plant genotypes and species (Obidiegwu et al., 2015; Pinheiro and Chaves, 2011).

Our previous study showed that tall fescue genotype RU9 exhibited drought tolerance whereas tall fescue genotype RU18 exhibited more drought sensitivity (Sun et al., 2013). Droughttolerant genotype RU9 may possess some unique proteins, upregulated stress-protection proteins, or proteins maintained to a greater extent than in drought-sensitive genotypes RU18, which would allow better plant survival of severe drought stress. The objective of this study was to identify drought-responsive proteins in leaves of tall fescue that differ from genotypes, which may be associated with superior drought tolerance in tall fescue. The identification of proteomic responses associated with genetic variations in drought tolerance of tall fescue will provide further insight into the molecular mechanisms of drought tolerance for cool-season perennial grass species.

\section{Materials and Methods}

Plant materials, growth conditions, and treatments. Sod of tall fescue genotypes RU9 and RU18 were planted in polyvinylchloride tubes (40-cm-deep and $20 \mathrm{~cm}$ diameter) with the bottom covered with nylon screen for drainage. The tubes were filled with a mixture $(1: 2, \mathrm{v} / \mathrm{v})$ of sand and soil (fine, montmorillonitic, mesic, Aquic, Arquidoll). Plants were established in a greenhouse at Rutgers University, New Brunswick, NJ, from 1 Sept. to 15 Oct. 2014. Greenhouse environmental conditions during plant establishment were $25 / 20{ }^{\circ} \mathrm{C}$ (day/ night), 66\% average relative humidity, and average photosynthetically active radiation $(P A R)$ of $660 \mu \mathrm{mol} \cdot \mathrm{m}^{-2} \cdot \mathrm{s}^{-1}$ provided by natural sun light. After $45 \mathrm{~d}$ of plant establishment, plants were then transferred to controlled-environment growth chambers (Environmental Growth Chambers, Chagrin Falls, OH) controlled at $23 / 18^{\circ} \mathrm{C}$ (day/night), $650 \mu \mathrm{mol} \cdot \mathrm{m}^{-2} \cdot \mathrm{s}^{-1} P A R, 60 \%$ relative humidity, and $12 \mathrm{~h}$ photoperiod during 16 Oct. to 2 Nov. 2014 to allow for plant acclimation to growth chamber conditions before the exposure to drought stress. Under both greenhouse and growth chamber conditions, plants were maintained in well-watered conditions by watering three times per week and provided with sufficient nutrition by applying halfstrength Hoagland's nutrient solution (Hoagland and Arnon, 1950) once per week. Plants were maintained at $9-10 \mathrm{~cm}$ canopy height by trimming the turf weekly.

Plants for both genotypes were exposed to well watered or drought stress on 3 Nov. 2014. Well-watered plants were irrigated three times per week to maintain soil water content (SWC) at the pot capacity (28\%). Drought stress was imposed by withholding irrigation for $12 \mathrm{~d}$ (from 3 to 15 Nov. 2014). Soil water content was monitored daily by time domain reflectometry (6050X1 Trase system I; Soilmoisture Equipment, Santa Barbara, CA) using $20-\mathrm{cm}$ stainless steel probes inserted vertically into the upper soil profile. By $12 \mathrm{~d}$ of drought stress, SWC declined to $6.2 \%$.

MeAsurements of Physiological PARAMaters. Leaf Pn was measured during the $12 \mathrm{~d}$ of treatment period (3-15 Nov. 2014) in mature leaves using a portable infrared gas analyzer (LI-6400;
LI-COR, Lincoln, NE) under CA (400 $\mu \mathrm{mol} \cdot \mathrm{mol}^{-1} \mathrm{CO}_{2}$, $500 \mu \mathrm{mol} \cdot \mathrm{s}^{-1}$ flow rate) and a LI-6400 external light source of light-emitting diode (providing a $P P F$ density of $600 \mu \mathrm{mol} \cdot \mathrm{m}^{-2} \cdot \mathrm{s}^{-1}$ ). Photosynthetic rate was measured on three samples of leaves in each pot, each sample with five leaves randomly selected from each pot.

Leaf photochemical efficiency was determined during the $12 \mathrm{~d}$ of treatment period (3-15 Nov. 2014) with a chlorophyll fluorometer (OS1-FL; Opti-Science, Hudson, NH). It was expressed as the ratio of variable fluorescence $(\mathrm{Fv})$ to maximum fluorescence $(\mathrm{Fm})$ of chlorophyll (Fv/Fm). Measurements were made on intact leaves with the fluorometer after the plants were adapted to darkness for $15 \mathrm{~min}$.

Protein extraction and labeling. Protein extraction was performed following the procedure described in a previous study from our laboratory (Liu et al., 2012). About $1 \mathrm{~g}$ of leaf samples were taken from a mixture of all leaves of plants in each pot at $12 \mathrm{~d}$ of treatment (15 Nov. 2014), washed free of sand, and immediately frozen in liquid nitrogen. Leaves were homogenized and incubated at $-20{ }^{\circ} \mathrm{C}$ for $12 \mathrm{~h}$ in extraction solution containing $5 \mathrm{~mL} 10 \% \mathrm{w} / \mathrm{v}$ trichloroacetic acid in acetone and $0.3 \%$ dithiothreitol (DTT). Proteins were further extracted in lysis buffer $\{7 \mathrm{M}$ urea, $2 \mathrm{M}$ thiourea, $65 \mathrm{~mm}$ DTT, 4\% 3-[(3cholamido-propyl)-dimethylammonio]-1-propanesulfonate (CHAPS), and $1 \%$ protease inhibitors $\}$, vortexed for $1 \mathrm{~h}$, and centrifuged at $14,000 \mathrm{gn}$ for $60 \mathrm{~min}$ to remove insoluble materials. Protein content was quantified using the 2D-Quant Kit (Amersham Biosciences, San Francisco, CA).

Two-dimensional Electrophoresis (2-DE). Protein separation and identification was performed using 2-DE and MS, respectively, following the procedure described by Liu et al. (2012). An Ettan IPGPhor3 apparatus (GE Healthcare, Piscataway, NJ) was used for isoelectric focusing (IEF) with immobilized $\mathrm{pH}$ gradient (IPG) strips ( $\mathrm{pH} 3-10, \mathrm{NL}$ gradient, $13 \mathrm{~cm})$. The IPG strips were rehydrated for $12 \mathrm{~h}$ at $20^{\circ} \mathrm{C}$ with $250 \mu \mathrm{L}$ of rehydration buffer ( $8 \mathrm{M}$ urea $+2 \%$ 3-[(3-cholamidopropyl) dimethylammonio]-1-propanesulfonate $+15 \mathrm{~mm}$ DTT + $0.002 \%$ bromophenol blue $+0.5 \%$ IPG buffer $\mathrm{pH} 3-10$ nonlinear) containing $300 \mu \mathrm{g}$ proteins. The voltage settings for IEF were $100 \mathrm{~V}$ for $3 \mathrm{~h}$, gradient $200 \mathrm{~V}$ for $3 \mathrm{~h}, 1000 \mathrm{~V}$ for $1 \mathrm{~h}$, gradient $8000 \mathrm{~V}$ for $3 \mathrm{~h}$, and $8000 \mathrm{~V}$ for $64,000 \mathrm{~V}$-hours to a total $18 \mathrm{~h}$. Following IEF, the protein in the strips was denatured with equilibration buffer [50 $\mathrm{mm}$ hydroxymethyl)aminomethane- $\mathrm{HCl}$ $\mathrm{pH} 8.8+6 \mathrm{~m}$ urea $+30 \%$ glycerol $+2 \%$ sodium dodecyl sulphatepolyacrylamide (SDS) $+1 \%$ DTT $+0.002 \%$ bromophenol blue] and then incubated with the same buffer containing $2.5 \%$ iodoacetamide instead of DTT for $20 \mathrm{~min}$. The two-dimensional electrophoresis was performed on a $12.5 \%$ gel using a vertical chamber (Hoefer SE 600, GE Healthcare) with standard protein markers (Fermentas, Waltham, MA) loaded at the left-most side. The gels were run at $10 \mathrm{~mA}$ per gel for the first $30 \mathrm{~min}$ and followed by $20 \mathrm{~mA}$ per gel. After SDS-polyacrylamide gel electrophoresis, gels were washed in deionized distilled $\mathrm{H}_{2} \mathrm{O}$ three times for $15 \mathrm{~min}$ and stained with colloidal Coomassie Blue G-250 (Neuhoff et al., 1988).

The 2-DE gels were scanned using Image Scanner (Amersham Biosciences Co., Little Chalfont, UK) and images were analyzed using Image Master 2D Platinum 6.0 software (GE Healthcare). To correct the variability because of staining, the abundance of each protein spot was estimated by the percentage volume. Only those proteins with significant (at least 1.5-fold change between control and treated samples) and reproducible 
changes were considered to be differentially accumulated proteins and further by MS analysis. Protein spots were cut off the preparative gels, de-stained with $100 \mathrm{mM} \mathrm{NH}_{4} \mathrm{HCO}_{3}$ in $30 \%$ acetonitrile (ACN). After removing the de-staining buffer, the gel pieces were lyophilized and rehydrated in $30 \mu \mathrm{L}$ of $50 \mathrm{~mm} \mathrm{NH}_{4} \mathrm{HCO}_{3}$ containing $50 \mathrm{ng}$ trypsin (sequencing grade; Promega, Madison, WI). After overnight digestion at $37^{\circ} \mathrm{C}$, the peptides were extracted three times with $0.1 \%$ trifluoroacetic acid in $60 \%$ ACN. Extracts were pooled together and lyophilized. The resulting lyophilized tryptic peptides were kept at $-80{ }^{\circ} \mathrm{C}$ until mass spectrometric analysis. A protein-free gel piece was treated as mentioned previously and used for a control to identify autoproteolysis products derived from trypsin.

All mass spectra were acquired on matrix-assisted laser desorption/ionization time-of-flight/time-of-flight tandem (MALDI-TOF/TOF) mass spectrometer 4800 Proteomics Analyzer (Applied Biosystems, Foster City, CA). Data were analyzed using GPS Explorer software (Applied Biosystems) and MASCOT software (Matrix Science, London, UK). National Center for Biotechnology nonredundant (NCBInr) database with Green Plant was used to search for the identification and functional annotation of protein spots. Peptide tolerance of $100 \mathrm{ppm}$, fragment mass tolerance of $\pm 0.5 \mathrm{Da}$, peptide charge of $1+$ were selected. Only
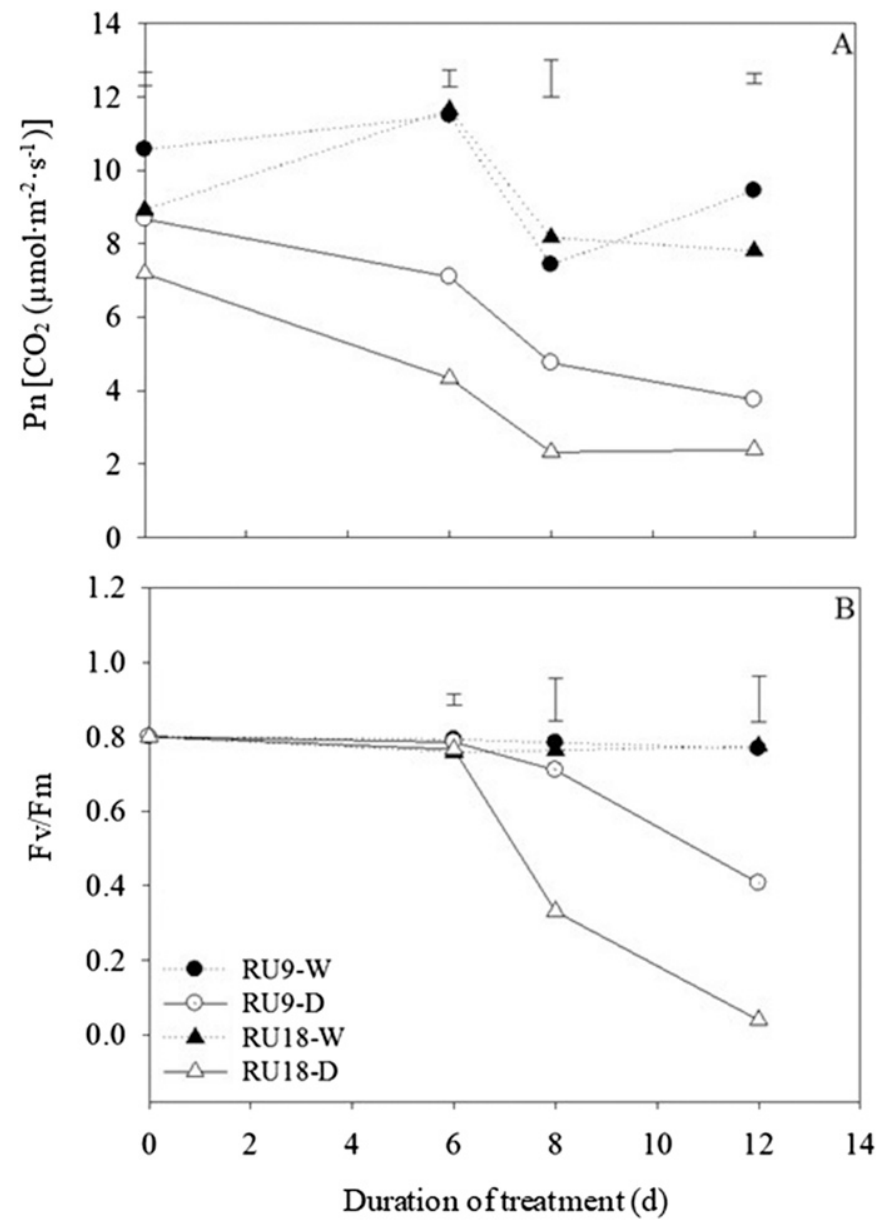

Fig. 1. Responses of leaf net photosynthetic rate (Pn) (A) and photochemical efficiency $(\mathrm{Fv} / \mathrm{Fm})(\mathbf{B})$ of RU9 and RU18 tall fescue to drought stress. Bars indicate least significant difference values $(P \leq 0.05)$ for comparisons between genotypes at a given day of treatment. $\mathrm{W}=$ well-watered control; $\mathrm{D}=$ drought stress treatment; $\mathrm{Fv}=$ variable fluorescence; $\mathrm{Fm}=$ maximum fluorescence. significant hits, as defined by the MASCOT probability analysis chilling injury $\%$ protein score $>95 \%$, were accepted.

EXPERIMENTAL DESIGN AND STATISTICAL ANALYSIS. The experiment was a complete randomized design with two factors (two watering treatments and two genotypes) with four replications for each treatment. All treatments and genotypes were randomly placed inside the growth chamber. Plants were relocated in the growth chamber every $3 \mathrm{~d}$ to ensure exposure to uniform environmental conditions.

Watering treatment effects and genotypic variations were tested by the analysis of variance procedure (SAS version 8.1; SAS Institute, Cary, NC). Significant difference between watering treatment or genotypes was determined using the least significant difference test at $P \leq 0.05$.

\section{Results and Discussion}

GENOTYPIC VARIATIONS OF TALL FESCUE IN PHYSIOLOGICAL RESPONSES TO DROUGHT STRESS. The previous study (Sun et al., 2013) reported that RU9 had superior drought tolerance over

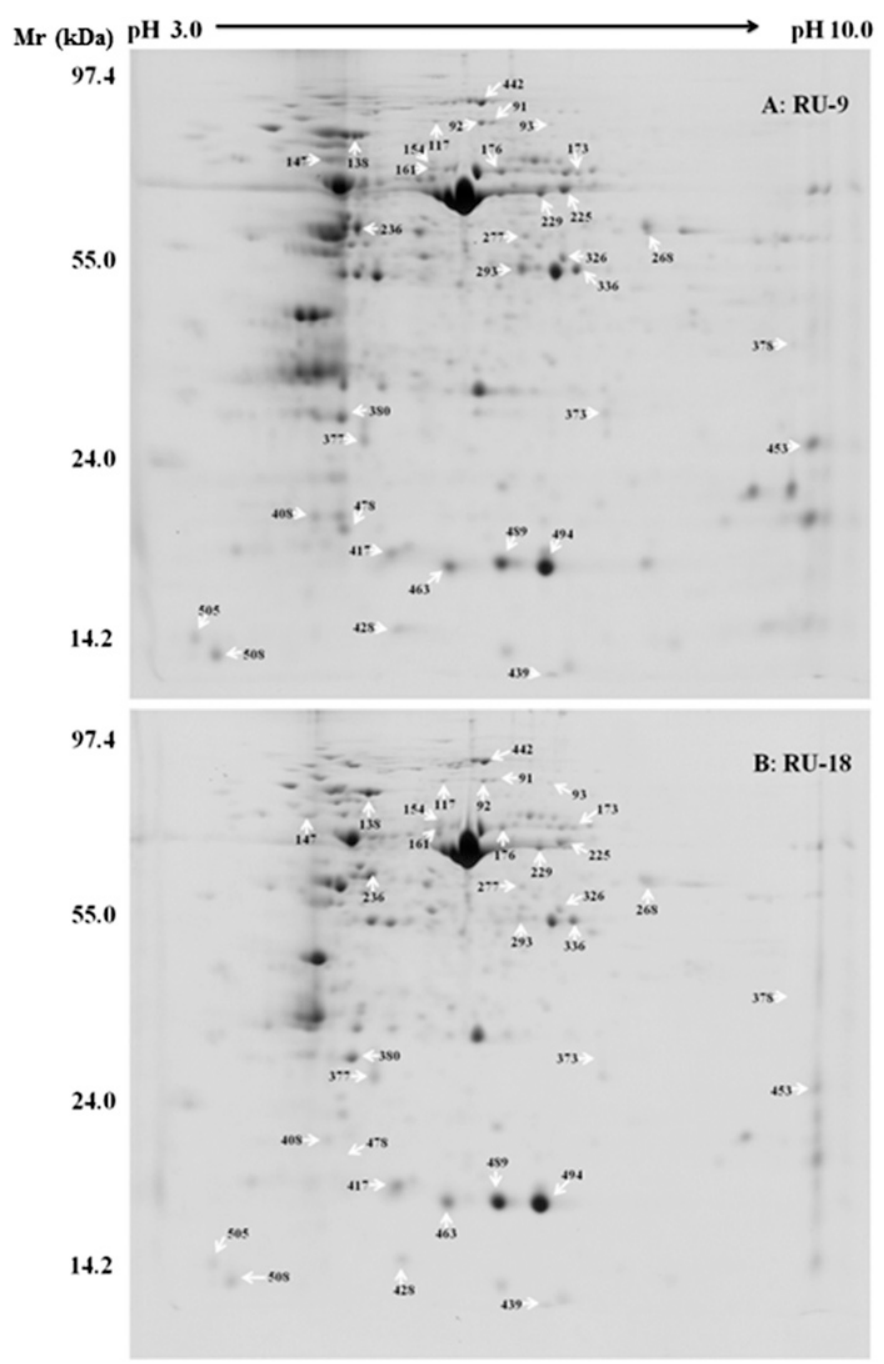

Fig. 2. Coomassie-stained two-dimensional polyacrylamide gel of separated proteins from RU9 and RU18 tall fescue leaves. Proteins were separated in the first dimension on an immobilized $\mathrm{pH}$ gradient strip at $\mathrm{pH} 3.0-10.0$ and in the second dimension on a $12.5 \%$ polyacrylamide gel showing molecular $(\mathrm{Mr})$ weight $(\mathrm{kDa})$. The numbered spots were identified by mass spectrometry. 
Table 1. Protein spots differently accumulated at $12 \mathrm{~d}$ of drought stress compared with well-watered conditions and between RU9 and RU18 tall fescue.

\begin{tabular}{|c|c|c|c|c|c|c|c|}
\hline \multirow[b]{2}{*}{$\mathrm{ID}^{\mathrm{z}}$} & \multirow[b]{2}{*}{ Protein name (species) } & \multirow[b]{2}{*}{$\mathrm{MW} / \mathrm{PI}$} & \multirow{2}{*}{$\begin{array}{l}\text { Accession } \\
\text { no. }\end{array}$} & \multicolumn{2}{|c|}{ Drought vs. control $^{y}$} & \multicolumn{2}{|c|}{ Genotype comparisons $^{\mathrm{y}}$} \\
\hline & & & & RU9D/RU9W & RU18D/RU18W & RU9W/RU18W & RU9D/RU18D \\
\hline \multicolumn{8}{|c|}{$\overline{\text { Category } 01 \text { metabolism }}$} \\
\hline 91 & $\begin{array}{l}\text { Methionine synthase } 2 \text { enzyme } \\
\text { (Hordeum vulgare) }\end{array}$ & $84 / 6.0$ & gi|68655500 & $\downarrow *$ & NS & $\uparrow *$ & NS \\
\hline 92 & $\begin{array}{l}\text { Methionine synthase } 1 \text { enzyme } \\
\text { (H. vulgare })\end{array}$ & $84 / 5.7$ & gi|68655495 & NS & NS & $\uparrow *$ & NS \\
\hline 442 & Glycine decarboxylase subunit & $11 / 6.5$ & gi|710308 & $\downarrow *$ & NS & NS & NS \\
\hline 225 & $\begin{array}{l}\text { Glycine hydroxymethyltransferase } \\
\text { (Oryza sativa Japonica group) }\end{array}$ & $61 / 8.8$ & gi|31126793 & NS & $\downarrow *$ & NS & NS \\
\hline \multicolumn{8}{|c|}{ Category 02 energy } \\
\hline 428 & $\begin{array}{l}\text { Photosystem I reaction center subunit } \mathrm{V} \text {, } \\
\text { chloroplast }\end{array}$ & $11 / 5.5$ & gi|149242533 & $\downarrow^{*}$ & NS & NS & NS \\
\hline 453 & $\begin{array}{l}\text { Photosystem I reaction center subunit II, } \\
\text { chloroplastic }\end{array}$ & 20/9.8 & gi|548603 & NS & NS & NS & $\uparrow *$ \\
\hline 478 & Rubisco small subunit (Lolium perenne) & $19 / 8.6$ & gi| 51475155 & $\uparrow^{*}$ & NS & NS & $\uparrow *$ \\
\hline 229 & Rubisco large subunit (Avena fatua) & $53 / 6.0$ & gi|57283794 & NS & $\downarrow^{*}$ & NS & NS \\
\hline 147 & $\begin{array}{l}\text { Rubisco large subunit-binding protein } \\
\text { subunit beta, chloroplastic }\end{array}$ & $54 / 4.9$ & gi| 2493650 & NS & NS & $\uparrow *$ & NS \\
\hline 494 & Rubisco small subunit (Triticum aestivum) & $20 / 8.8$ & gi|11990897 & $\downarrow *$ & NS & $\downarrow *$ & $\downarrow^{*}$ \\
\hline 326 & $\begin{array}{l}\text { Glyceraldehyde-3-phosphate } \\
\text { dehydrogenase (GADPH), cytosolic } 1\end{array}$ & $37 / 6.5$ & gi $\mid 120670$ & NS & NS & NS & $\uparrow^{*}$ \\
\hline 293 & GADPH (383 AA) (Zea mays) & $41 / 7.2$ & gi|22240 & $\uparrow *$ & NS & NS & NS \\
\hline 176 & $\begin{array}{l}\text { ATP synthase CF1 alpha subunit } \\
\text { (L. perenne) }\end{array}$ & $56 / 6.1$ & gi|159106861 & $\downarrow *$ & $\downarrow *$ & $\downarrow *$ & NS \\
\hline 380 & $\begin{array}{l}\text { ATP synthase CF1 alpha subunit } \\
\text { (Saccharum hybrid) }\end{array}$ & $55 / 5.9$ & gi|50812525 & $\downarrow *$ & NS & NS & NS \\
\hline 236 & Phosphoglycerate kinase & $50 / 6.6$ & gi|129915 & $\downarrow *$ & NS & NS & NS \\
\hline 138 & Transketolase, chloroplastic & $73 / 5.5$ & gi| 159106861 & NS & NS & NS & $\downarrow *$ \\
\hline \multicolumn{8}{|c|}{ Category 05 protein degradation } \\
\hline 439 & Ubiquitin-60S ribosomal protein L40 & $15 / 10$ & gi|302393709 & $\uparrow *$ & NS & NS & NS \\
\hline \multicolumn{8}{|c|}{ Category 11 Stress defense } \\
\hline 173 & Catalase (Lolium arundinacea) & $57 / 6.4$ & gi|90264977 & $\downarrow *$ & NS & NS & NS \\
\hline 463 & $\begin{array}{l}\text { Glutaredoxin family protein } \\
\text { (Arabidopsis thaliana) }\end{array}$ & $31 / 9.3$ & gi|332657511 & NS & $\uparrow *$ & NS & NS \\
\hline \multicolumn{8}{|c|}{ Category 12 Unclassified } \\
\hline 277 & $\begin{array}{l}\text { Os02g0101500 (O. sativa Japonica } \\
\text { Group) }\end{array}$ & $42 / 6.6$ & gi|115443619 & NS & $\downarrow *$ & NS & NS \\
\hline 268 & $\begin{array}{l}\text { Hypothetical protein SORBIDRAFT_ } \\
\text { 06g029020 (Sorghum bicolor) }\end{array}$ & $44 / 8.4$ & gi|242074370 & NS & $\downarrow^{*}$ & $\downarrow *$ & NS \\
\hline 93 & $\begin{array}{l}\text { Hypothetical protein OsJ_10295 } \\
\text { (O. sativa Japonica Group) }\end{array}$ & $61 / 8.1$ & gi|222624643 & NS & NS & $\downarrow *$ & NS \\
\hline 408 & Unknown & & & $\uparrow^{*}$ & NS & NS & NS \\
\hline 505 & Unknown & & & NS & NS & NS & $\uparrow^{*}$ \\
\hline 508 & Unknown & & & NS & NS & $\uparrow^{*}$ & $\uparrow *$ \\
\hline 378 & Unknown & & & NS & $\downarrow^{*}$ & NS & NS \\
\hline 154 & Unknown & & & $\downarrow^{*}$ & $\uparrow^{*}$ & $\uparrow *$ & NS \\
\hline 161 & Unknown & & & NS & NS & $\uparrow *$ & NS \\
\hline 373 & Unknown & & & NS & NS & $\downarrow *$ & NS \\
\hline 377 & Unknown & & & NS & NS & $\downarrow *$ & NS \\
\hline 489 & Unknown & & & $\downarrow^{*}$ & NS & NS & $\uparrow^{*}$ \\
\hline
\end{tabular}

${ }^{\mathrm{z}}$ Spot identification in Fig. 2.

${ }^{\mathrm{y}} \downarrow$ and $\uparrow$ indicate 1.5 -fold lower protein abundance and 1.5-fold higher abundance, respectively, comparing drought-stressed plants to wellwatered plants for each genotype (RU9D/RU9W, RU18D/RU18W) and comparing between RU9 to RU18 under well-watered conditions (RU9W/RU18W) and under drought stress conditions (RU9D/RU18D).

Ns, * Nonsignificant or significant difference, respectively, between drought and well-watered treatments and between genotypes at $P \leq 0.05$. RU9D = drought-stressed RU9; RU18D = drought-stressed RU18; RU9W = well-watered RU9; RU18W = well-watered RU18. 
RU18, as shown by the greater turf quality, relative water content, and cell membrane stability in RU9 than RU18 exposed to drought stress. In the present study, physiological drought tolerance was evaluated by leaf Pn and Fv/Fm. Leaf Pn (Fig. 1A) and Fv/Fm (Fig. 1B) decreased in both genotypes with increasing stress duration but the rate of decline in RU18 was much greater than RU9. Pn of RU9 was significant higher than RU18 from $6 \mathrm{~d}$ of drought treatment. At the end of drought treatment (12 d), Pn of RU18 decreased to 0.747 (43.68\% of the control level) whereas Pn of RU9 decreased only to 0.823 (41.76\% of the control level). Fv/Fm decreased much greater than that of $\mathrm{Pn}$ in both genotypes under drought treatment. At 8 and $12 \mathrm{~d}$ of drought treatment, Fv/Fm of RU9 was 0.71 and 0.41 , however Fv/Fm of RU18 was 0.33 and 0.04 , Fv/Fm of RU9 was significantly higher than RU18. The data with Pn and Fv/Fm confirmed the previous finding that RU9 and RU18 exhibited differential drought tolerance (Sun et al., 2013). The genotypic variations in the physiological responses to drought stress in tall fescue could be associated with the alteration of protein accumulation under drought stress, as discussed in the following paragraphs.

DifFERENTIALLY EXPRESSED PROTEINS ASSOCIATED WITH DIFFERENTIAL DROUGHT TOLERANCE IN TWO GENOTYPES OF TALL FESCUE. Protein metabolism is sensitive to drought stress, and therefore, a large number of proteins may be upregulated or downregulated by drought stress, as shown on 2-DE gels from leaf extracts of tall fescue (Fig. 2). A total of 31 protein spots exhibited significant changes in abundance above 1.5-fold between genotypes in response to drought stress, 22 of them were successfully identified by MALDI TOF/TOF (Fig. 2; Table 1). These proteins identified were classified into five categories including metabolism, energy, protein degradation, stress defense, and unknown category based on the NCBI database.

Protein spots differentially accumulated under drought stress compared with well-watered conditions (drought vs. control, RU9D/RU9W, RU18D/RU18W), between RU9 and RU18 under well-watered conditions (RU9W/RU18W), and between RU9 and RU18 under drought stress (RU9D/RU18D) are presented in Table 1 . Among the 22 protein spots, four spots (478, 293, 439, and 463) exhibited significant increases in abundance (upregulated) and 12 spots (91, 442, 225, 428, 229, $494,176,380,236,173,277$, and 268) had declined in abundance (downregulated) comparing drought with well-watered

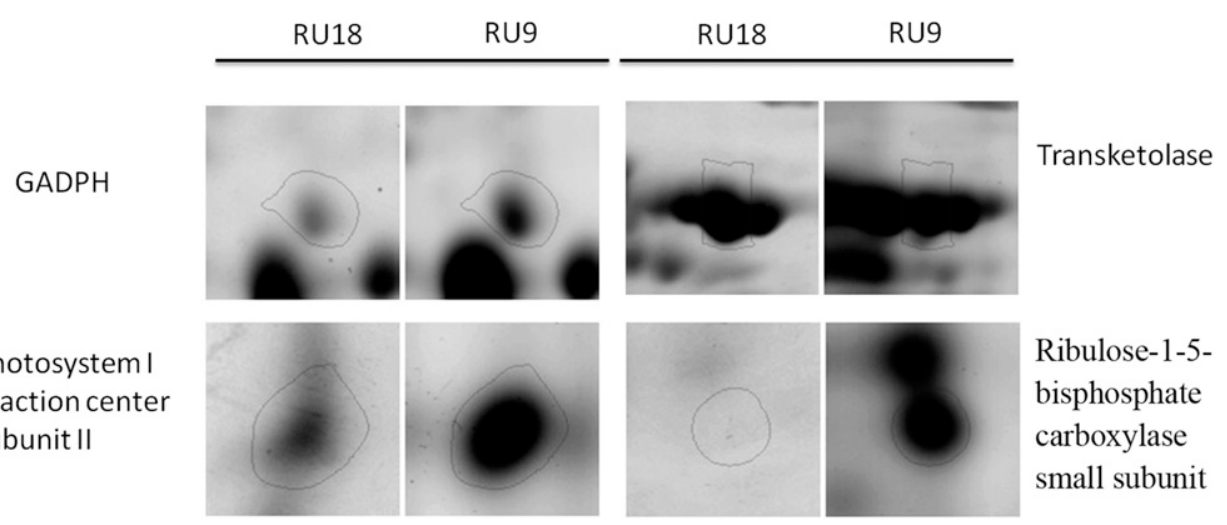

Fig. 3. Comparison of photosynthesis-related protein spots between RU9 and RU18 tall fescue exposed to $12 \mathrm{~d}$ of drought stress. conditions, suggesting that those are drought-responsive proteins. Among the 12 downregulated protein spots by drought stress, eight of them (spot 91, 442, 428, 494, 176, 380, 236, and 173) were found in RU9 and five proteins (spot 225, 229, 176, 277, and 268) were found in RU18.

It should be noted that not all drought-responsive proteins are positively associated with drought tolerance, and changes in the abundance or expression levels for some proteins could be the result of drought damages unless differentially expressed proteins are analyzed and compared between at least two genotypes contrasting in drought tolerance (Zhou et al., 2014). Therefore, in this study, we are mainly interested in the proteins differentially expressed between the two genotypes under drought stress, which may explain the genotypic variations in drought tolerance of tall fescue.

Among the identified proteins, three protein spots $(453,478$, and 326) exhibited higher abundance in RU9 compared with those in RU18 when both genotypes were exposed to drought stress. The higher abundance proteins in RU9 all belong to the functional category of energy metabolism, including photosystem I reaction center subunit II (spot 453), Rubisco small subunit (spot 478), and GADPH (spot 326) (Table 1; Fig. 3). Photosystem I reaction center subunit II is an integral membrane protein complex that uses light energy to produce the high-energy carriers, adenosine triphosphate (ATP) and nicotinamide-adenine dinucleotide phosphate (NADPH) in the light reaction of photosynthesis (Amunts et al., 2007; Golbeck, 1987). Downregulation of PS I reaction center subunit II led to low PS I activity (Henkes et al., 2001). Rubisco protein is a key enzyme for carboxylation to produce carbohydrate in the dark reaction of photosynthesis (Demirevska et al., 2008). The elevated abundance level of Photosystem I reaction center subunit II and Rubisco small subunit could contribute to the maintenance of higher Fv/Fm and Pn in RU9 than RU18 through regulating both ATP synthesis in the light reaction and carbon assimilation in the dark reaction of photosynthesis. The GADPH enzyme catalyzes the breakdown of glucose to release energy in glycolysis and is highly responsive to drought stress (Yang et al., 1993). The greater abundance of GADPH indicated that RU9 could be better able to maintain respiration to provide ATP energy for supporting plant growth and metabolic activities under drought stress.

Of the 22 drought-responsive proteins, four protein spots (138, 489, 505, and 508) had lower abundance in RU9 compared with those in RU18, when both genotypes were exposed to drought stress. The spot 138 was identified as transketolase chloroplastic protein whereas spot 489, 505, and 508 could not be characterized in terms of their functions using MS based on the current database. Transketolase enzymes are involved in multiple metabolic processes, including the synthesis of carbohydrates (i.e., pentose), aromatic amino acids (i.e., erythrose), and natural products (i.e., thiamine pyrophosphate or vitamin B1) (Henkes et al., 2001), and they also participate in oxidative regulation in chloroplasts during light reaction of photosynthesis (Balmer et al., 2003). Transketolases can be present in 
oxidized (inactive form) and reduced (active) forms; the reduction of the oxidized form of transketolase by thioredoxin would relieve inhibition and restoration of the full catalytic activity and facilitate the biochemical resources for antioxidant defense (Balmer et al., 2003). The downregulation of transketolase in RU9 under drought stress could be related to the oxidative regulation in leaves of tall fescue. However, the underlying mechanisms for its role in regulating antioxidant defense for drought tolerance are unknown and deserve further investigation.

In summary, this study identified 31 drought-responsive proteins with 1.5 fold change in the abundance in response to drought stress in both cultivars of tall fescue, and among them, four were differentially expressed between the drought-tolerant genotypes (RU9) and drought-sensitive genotype (RU18). All those differentially expressed proteins in the two genotypes (photosystem I reaction center subunit II, Rubisco small subunit, GADPH and transketolase) were found to be involved in photosynthesis, respiration, or oxidative regulation, suggesting the critical importance of energy and oxidative metabolism in tall fescue adaptation to drought stress. Those proteins could be used as biomarkers or developed to molecular markers to develop elite drought-tolerant germplasm in tall fescue and other cool-season perennial grass species.

\section{Literature Cited}

Ali, G.M. and S. Komatsu. 2006. Proteomic analysis of rice leaf sheath during drought stress. J. Proteome Res. 5:396-403.

Amunts, A., O. Drory, and N. Nelson. 2007. The structure of a plant photosystem I supercomplex at 3.4 a resolution. Nature 447:58-63.

Balmer, Y., A. Koller, G. del Val, W. Manieri, P. Schürmann, and B.B. Buchanan. 2003. Proteomics gives insight into the regulatory function of chloroplast thioredoxins. Proc. Natl. Acad. Sci. USA 100:370-375.

Demirevska, K., L. Simova-Stoilova, V. Vassileva, and U. Feller. 2008. Rubisco and some chaperone protein responses to water stress and rewatering at early seedling growth of drought sensitive and tolerant wheat varieties. Plant Growth Regulat. 56:97-106.

Ebrahimiyan, M., M.M. Majidi, A. Mirlohi, and A. Noroozi. 2013. Physiological traits related to drought tolerance in tall fescue. Euphytica 190:401-414.

Faghani, E., J. Gharechahi, S. Komatsu, M. Mirzaei, R.A. Khavarinejad, F. Najafi, L.K. Farsad, and G.H. Salekdeh. 2015. Comparative physiology and proteomic analysis of two wheat genotypes contrasting in drought tolerance. J. Proteomics 114:1-15.

Fry, J. and B. Huang. 2004. Applied turfgrass science and physiology. Wiley, Hoboken, NJ.

Golbeck, J.H. 1987. Structure, function and organization of the photosystem I reaction center complex. Biochim. Biophys. Acta 895:167-204.
Henkes, S., U. Sonnewald, R. Badur, R. Flachmann, and M. Stitt. 2001. A small decrease of plastid transketolase activity in antisense tobacco transformants has dramatic effects on photosynthesis and phenylpropanoid metabolism. Plant Cell 13:535-551.

Hoagland, D.R. and D.I. Arnon. 1950. The water culture method for growing plants without soil. California Agr. Expt. Sta. Circ. 347.

Khan, M.N. and S. Komatsu. 2016. Proteomic analysis of soybean root including hypocotyl during recovery from drought stress. J. Proteomics 144:39-50.

Kosmala, A., D. Perlikowski, I. Pawłowicz, and M. Rapacz. 2012. Changes in the chloroplast proteome following water deficit and subsequent watering in a high- and a low-drought-tolerant genotype of Festuca arundinacea. J. Expt. Bot. 63:6161-6172.

Liu, Y., H. Du, X. He, B. Huang, and Z. Wang. 2012. Identification of differentially expressed salt-responsive proteins in roots of two perennial grass species contrasting in salinity tolerance. J. Plant Physiol. 169:117-126.

Mefti, M., H. Bouzerzour, E. Francia, A. Ulrici, A. Abdelguerfi, P. Barre, and N. Pecchioni. 2016. Agronomic and molecular evaluation of cocksfoot and tall fescue cultivars for adaptation to an Algerian drought-prone environment. Euphytica 212:371-386.

Neuhoff, V., N. Arold, D. Taube, and W. Ehrhardt. 1988. Improved staining of proteins in polyacrylamide gels including isoelectric focusing gels with clear background at nanogram sensitivity using Coomassie Brilliant Blue G-250 and R-250. Electrophoresis 9:255262.

Obidiegwu, J.E., G.J. Bryan, H.G. Jones, and A. Prashar. 2015. Coping with drought: Stress and adaptive responses in potato and perspectives for improvement. Front. Plant Sci. 6:542.

Pinheiro, C. and M.M. Chaves. 2011. Photosynthesis and drought: Can we make metabolic connections from available data? J. Expt. Bot. 62:869-882.

Pirnajmedin, F., M.M. Majidi, and M. Gheysari. 2015. Root and physiological characteristics associated with drought tolerance in Iranian tall fescue. Euphytica 202:141-155.

Salehi, M., H. Salehi, A. Niazi, and C. Ghobadi. 2014. Convergence of goals: Phylogenetical, morphological, and physiological characterization of tolerance to drought stress in tall fescue (Festuca arundinacea Schreb.). Mol. Biotechnol. 56:248-257.

Sun, J., W. Meyer, J. Cross, and B. Huang. 2013. Growth and physiological traits of canopy and root systems associated with drought resistance in tall fescue. Crop Sci. 53:575-584.

Wang, N., J. Zhao, X. He, H. Sun, G. Zhang, and F. Wu. 2015. Comparative proteomic analysis of drought tolerance in the two contrasting Tibetan wild genotypes and cultivated genotype. BMC Genomics 16:432.

Yang, Y., H.B. Kwon, H.P. Peng, and M.C. Shih. 1993. Stress responses and metabolic regulation of glyceraldehyde-3-phosphate dehydrogenase genes in Arabidopsis. Plant Physiol. 101:209-216.

Zhou, P., Y. An, Z. Wang, H. Du, and B. Huang. 2014. Characterization of gene expression associated with drought avoidance and tolerance traits in a perennial grass species. PLoS One 9: e103611. 